\title{
Whose Utopia? Perspectives on the West-Eastern Divan Orchestra
}

\author{
RACHEL BECKLES WILLSON
}

Daniel Barenboim devoted one of his 2006 BBC Reith Lectures to the idea of "Meeting in Music," and focused on the West-Eastern Divan Orchestra, his ensemble of young musicians from Arab, Jewish, and Spanish backgrounds. ${ }^{1}$ He conceptualized the orchestra as a "utopian republic," but he also played down its political significance by asserting that its utopian quality was a function of music. In music, he explained, one had to be aware not only of oneself but also of "the other," so that music was "in this case not an expression of what life is, but an expression of what life could be, or what it could become." When in conversation with Edward W. Said, who was involved in the orchestra's early years, Barenboim was nevertheless also enthusiastic about its directly political implications, and the two of them agreed that it had demolished Arab stereotypes about Israelis, and Israeli stereotypes about Arabs. ${ }^{2}$ The "utopian republic," then, was a model for a Middle East in which the various peoples listened to and understood one another without prejudice.

In a by-now iconic essay on utopia in musicals and variety shows, Richard Dyer has demonstrated some of the ways that musical genres offer audiences apparent remedies for (or at least escapes from) the problems that they face in life. ${ }^{3}$ Instead of scarcity these entertainments present abundance, and counteracting exhaustion they express energy; they replace dreariness with intensity, manipulation with transparency, and social fragmentation with community. This last substitution may seem close to the West-Eastern Divan Orchestra as constructed by Barenboim and Said, in that Arabs and Jews work through music to become an interactive and productive sociality, in contrast to the destructive conflict that the majority are understood as living out in real life.

In his essay Dyer also engages with some of the more complex aspects of utopian musical entertainments, however, pointing out that by offering escape from certain types of suffering, they covertly define the type of suffering that is open to discussion. ${ }^{4}$ We might compare this with the West-Eastern Divan Orchestra's utopia, which corrects a specific type of suffering (feeling misunderstood by "the

\footnotetext{
This article is one of two that result from research funded by a Small Grant from the British Academy and a Small Grant from the Arts and Humanities Research Council. I am grateful to Daniel Barenboim and Mariam Said for allowing me to be present during the West-Eastern Divan Orchestra's workshop and tour in 2006. My thanks are also due to its organizers, in particular Tabaré Perlas and Nicole Foster; as well as to all former and current participants who spoke with me, and to staff at the Barenboim-Said Foundation who sent me archived reviews of the orchestra's tours of 2005 and 2006 . I also offer thanks to two anonymous readers whose advice enabled me to improve earlier forms of this article substantially. Errors remaining are my own.

${ }^{1}$ Reith Lectures 2006. No. 4, "Meeting in Music.” All Barenboim's Reith Lectures can be accessed at http://www.bbc.co.uk/radio4/reith2006/lectures.html

${ }^{2}$ See Paul Smaczny, Daniel Barenboim: 50 Years of Stage [Film] (Stuttgart: EuroArts Music International, 2000), Track 11, and Daniel Barenboim and Edward W. Said, Parallels and Paradoxes: Explorations in Music and Society, ed. and with a preface by Ara Guzelmian (London: Bloomsbury Publishing, 2002), 6-10.

${ }^{3}$ Richard Dyer, "Entertainment and Utopia," in Only Entertainment (London and New York: Routledge, 2002), 19-35.

${ }^{4}$ Dyer, 26-27.
} 
other"), while most suffering in the Middle East is economic and political—in many areas to extreme states of existential crisis. Dyer also argues effectively that entertainment implies a sense of absence that can be magicked away by capitalism, while entertainment genres themselves depend on the success of capitalism. They are thus often self-serving: as he expresses it, "entertainment provides alternatives to capitalism which will be provided by capitalism." The circularity of the problem-solving process is to be traced in the West-Eastern Divan Orchestra too, as it projects a utopia in Europe and for European audiences, while this is not necessarily one that people in the Middle East seek. ${ }^{6}$ Finally, Dyer makes three short case studies to show that utopian entertainments are not necessarily straightforward presentations of solutions to life's problems, for they contain contradictions within themselves. ${ }^{7}$ As is to be expected, the players of the West-Eastern Divan Orchestra are by no means unified in character or opinion, even if they combine to achieve admirable musical performances.

Elsewhere I have explored that internal heterogeneity in some detail, drawing on fieldwork and archival research undertaken between 2005 and 2008. ${ }^{8}$ My aim here however, even while I draw partially on my earlier fieldwork, is to consider the West-Eastern Divan Orchestra as utopian entertainment. The primary reason for taking this approach is the orchestra's public presentation of a "story": the orchestra has a narrative function that justifies its musical existence, and it plays in public stadia and open spaces where it attracts mass audiences. The further reason is that I am concerned to explore how the performances of that story become entangled with the musical repertoire selected. One of the works chosen in 2006, namely Beethoven's Symphony no. 9, contributed considerably to the orchestra's narrative entertainment potential. This very popular work is already associated with moments of heightened community emotion and political activity, and in August 2006 its performance coincided with the very harsh reality of an ongoing war between the Israeli Defence Forces and Hezbollah. Thus the symphonic presentation of Friedrich Schiller's Ode to Joy created an extreme confluence of happy utopia and miserable actuality.

The apparatus I use to construct the concerts is drawn from the work of anthropologist Alfred Gell. Gell construes "art" as a function of a range of social actors that form networks over time and space. ${ }^{9}$ His approach bypasses separatist notions of "work" or "performer," offering instead a model for analysing relations between people, objects, actions, and symbolic meanings. I will suggest in the first section below that it opens out a new space for exploring complex social constellations involving music. ${ }^{10}$ My aim thereby is to demonstrate the multifaceted significance of West-Eastern Divan Orchestra concerts and their dependence on a set of competing utopian projects.

\footnotetext{
${ }^{5}$ Dyer, "Entertainment and Utopia," 27.

${ }^{6}$ The orchestra has also played in the U.S.A., Morocco, and-famously-in Ramallah. Nevertheless the emphasis is in Europe, and the reception in Ramallah (which would be a subject for a separate study) was by no means in line with (say) the reception in Madrid.

${ }^{7}$ Dyer, "Entertainment and Utopia," 28ff.

${ }^{8}$ Rachel Beckles Willson, “The Parallax Worlds of the West-Eastern Divan Orchestra,” Fournal of the Royal Musical Association (forthcoming in November 2009). This article contains more extensive reference to interviewees. There, and here, too, I refer to players who provided me with information and commentary (between 2005 and 2008) by invented initials, because a large number of them wished to preserve their anonymity.

${ }^{9}$ Alfred Gell, Art and Agency: An Anthropological Theory (Oxford: Oxford University Press, 1999).

${ }^{10}$ Georgina Born has used music to experiment with Gell's theory, but primarily in order to explore genres of music beyond the western classical tradition. See Georgina Born, "On Musical Mediation: Ontology, Technology, and Creativity," twentiethcentury music 2, no.1 (2005): 7-36.
} 


\section{Beethoven against Violence}

Alfred Gell's theorization relies on breaking down the social networks around artistic events into the ways in which some kind of entity (a person, or an idea) exerts influence over another. He categorizes the former as Agent, and the latter as Patient. As an example, we might say that the conflict in Israel and Palestine acted as an Agent when it provoked a man called Bernd Kaufmann (Patient). In his concern to respond, and in his capacity as Director of Weimar's Cultural Capital of Europe events in 1999, he acted as Agent to seek a musician (Patient) to create something with him. Empowered by this invitation, that musician (Barenboim) joined him to become an Agent, and together they gathered and conducted young players, mature musicians and Edward Said (all those gathered were Patients in this role, but were potential Agents within the project). The consequence was-within a couple of years-the West-Eastern Divan Orchestra. This schematic chain of events can be placed on a tree diagram, following Gell, as illustrated in Fig. 1. Agents are all on the left, and the process begins at the bottom, moving chronologically upwards from Kaufmann's desire to respond to the conflict between Palestinians and Israelis, towards a musical enactment of Arab and Israeli coexistence. ${ }^{11}$

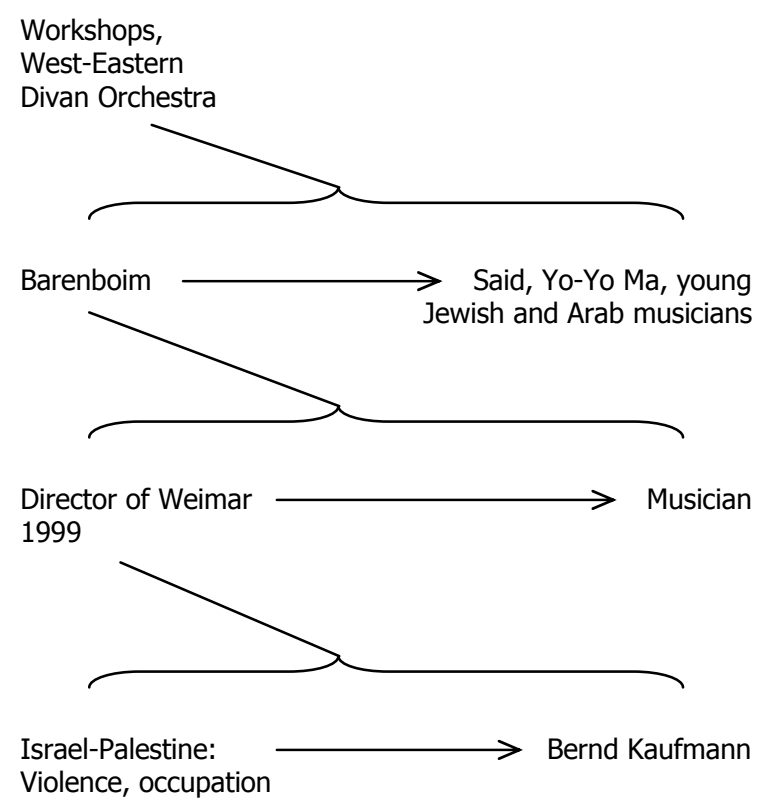

Figure 1

\footnotetext{
${ }^{11}$ Although Goethe's poetry collection West-Östlische Diwan provided an attractive name for the orchestra, and the first workshop gathering was at Weimar's Cultural Capital of Europe festivities in 1999 that coincided with the 250th anniversary of Goethe's birth, it was not apparently the initial impulse for it. In fact Goethe's interest in the poetry of the Orient is greatly at odds with Barenboim and Said's neglect of music from Arabic traditions. Barenboim himself refers to Bernd Kaufman as the one who provided the "impetus." See Paul Smaczny, The Ramallah Concert-Knowledge Is the Beginning and West-Eastern Divan Orchestra/Barenboim (EuroArts Music International and WarnerClassics, 2005), Track 2.
} 
We can take this further by considering the genealogy of Beethoven 9, and plotting that too on a tree diagram. This symphony is exceptionally rich in utopian terms: it consists of a model society (symphony orchestra), a community (choir), and an affirmative, visionary text. ${ }^{12}$ And the history of the text delineates a shift from an apparently realizable hope to a utopia. When Schiller first wrote his Ode in 1785, he was inspired by currently prevailing ideals of human liberty: they led him to write of "universal" love as "the bond that unites all men," and of the "correlation between individual happiness and the perfection of society." ${ }^{13}$ But he retracted the 1785 version of his text, presumably because the ideals had been shattered by the violence of the French Revolution-which was commenced in the name of human liberty. The version with which he replaced the original in 1803 was still idealistic, but was reordered to suggest a progression from earth towards the heavens, creating thereby a path to something profoundly disconnected from worldly society. Fig. 2 shows how the ideals of human liberty (Agent) inspired artists such as writers and composers (as Patients). In the next level up I have placed Beethoven as an Agent acting upon a Patient (Schiller's Ode to Joy), and on the next level up, his Ninth Symphony.

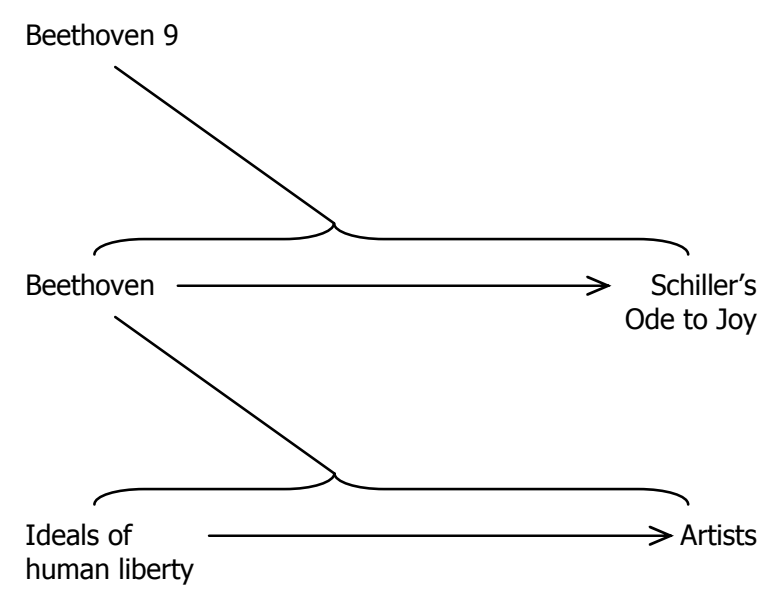

Figure 2

At this point it is worth pausing and considering what we gain from these diagrams. As Georgina Born has observed of Gell, his work is structuralist, and can lend itself to the by-now much-criticized construction of bounded wholes. ${ }^{14}$ The diagrams may over-simplify processes (my Beethoven 9 genealogy is a rather extreme example of this). They may seem to reify fluid and unpredictable processes and may even appear to wrench them artificially from history. Yet the reductive move has considerable value, I suggest, because it can be used as a first step towards constructing complexity in new ways. And, as Born argues, Gell's arguments about agency and networks do not necessarily lead towards closure: on the contrary, they critique existing concepts of art and anthropology, and simultaneously open up new connections.

\footnotetext{
${ }^{12}$ See Mark Evans Bonds, Music as Thought: Listening to the Symphony in the Age of Beethoven (Princeton, New Jersey: Princeton University Press, 2006).

${ }^{13}$ Nicholas Cook, Beethoven Symphony No. 9 (Cambridge: Cambridge University Press, 1993), 101.

${ }^{14}$ See Born, 19-20.
} 
To make these points clear, let us look at the position of Beethoven 9 itself once it is placed within a more complex network. The aim now is to ensure that this work is not understood as part of a bounded system, that it remains understood as a product of history, and that its multivalence is not foreclosed. In Fig. 2 it appears as a historical product of Beethoven's work on the Schiller text, and is also a potential Agent, placed on the left side of the tree. Indeed it will act upon recipients such as audiences and critics on the Patient side, creating a complex reception history that could be traced in an unfolding series above. Its historicity, then, is clear. In the more complex Fig. 3, however, it takes a different position, namely on the Patient side. Here it is acted upon by the West-Eastern Divan Orchestra (Agent) which takes it as a vehicle with which the orchestra can proclaim ideals of liberty and coexistence (Schiller's "every man becomes a brother") in music. The West-Eastern Divan Orchestra and Beethoven 9 (each with their histories), protrude into the future in a potential series of reactions.

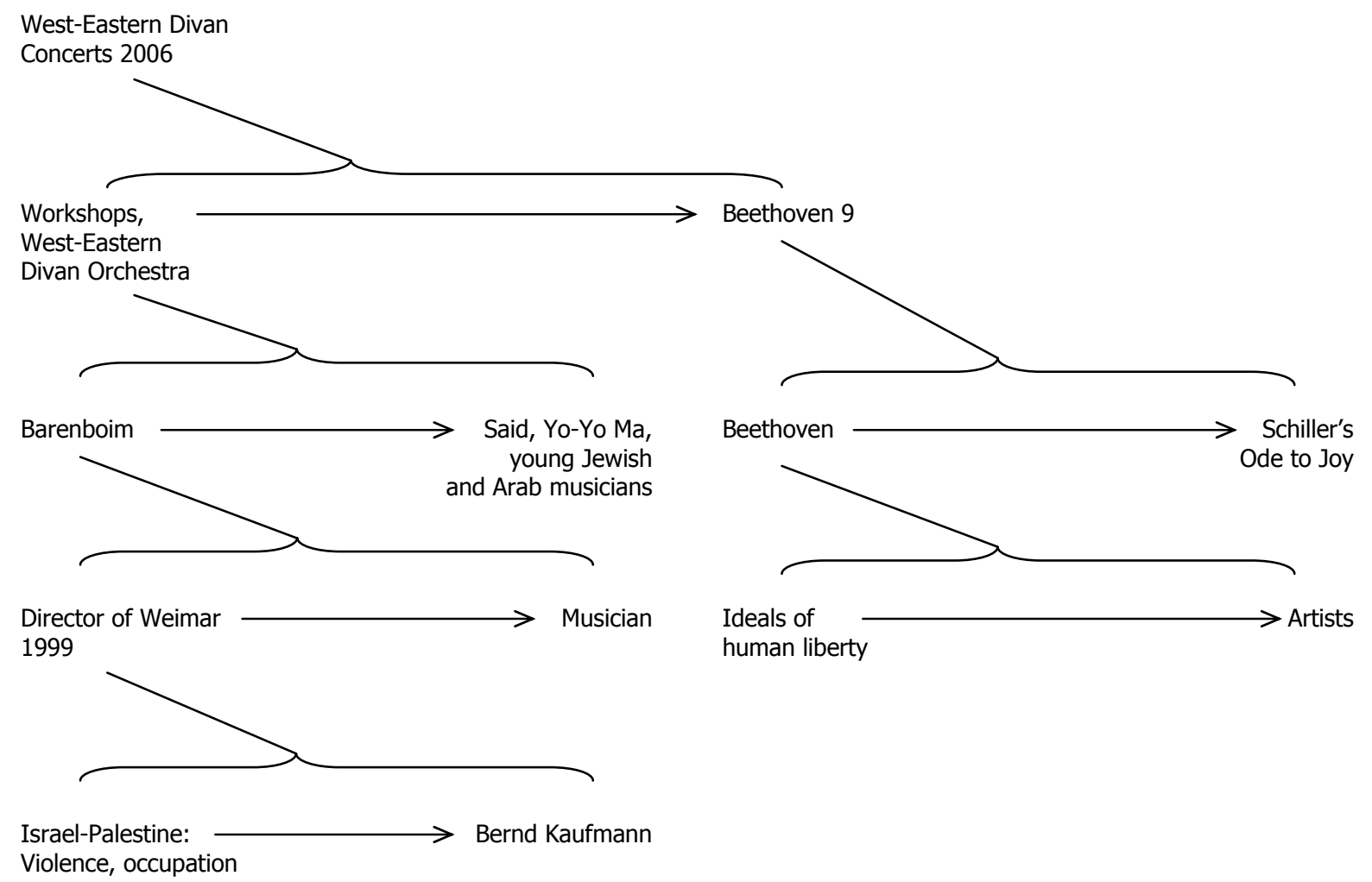

Figure 3

Beethoven 9, then, is not wholly determined by any history or context here: the diagrams suggest, rather, a contingent cumulation. There is a classic Gell analysis underlying this layering, namely Mary Richardson's attack on Velázquez's Rokeby Venus. Once the much-admired painting of a naked woman was slashed by a feminist activist, it acquired a new layer of meaning that worked backwards into earlier meanings, and opened up towards a future of new ones. ${ }^{15}$ Clearly the West-Eastern Divan Orchestra can be read similarly as a fluid entity here-and of this, more below.

\footnotetext{
${ }^{15}$ Gell, 62-64. This confluence is also discussed in Born, 18-19.
} 
Some of the meanings that accrued to the meeting of Beethoven 9 and the West-Eastern Divan Orchestra can be gleaned from press responses in 2006. In the following quotation from Carlos Colón's article "Peace Needs Beethoven," which appeared in response to the concerts in Seville and Madrid, the lowly players appear glued together by music. This is apparently thanks to two forces, namely the lofty conductor, and the yet more significant super solution-provider, Beethoven:

Among the young Israeli, Arab and Spanish musicians who congregate within Barenboim's West-Eastern Divan Orchestra, the universal language which unifies them is music. In each stand there is a score and, in front of them all, the conductor who makes it possible that individualities, without disappearing, are blended and harmonized to produce this timeless emotion together, this exaltation of tragedy and of the glory of the human being expressed only by classical music. And, beyond the conductor and the musicians, Beethoven and his Ninth Symphony as a symbol of the best work which a human being can produce when reason dominates passion without diminishing its strength. ${ }^{16}$

This writer's thinking is indebted to romantic work ontologies, and erases many of the realities of the contemporary social action that Gell's work would tend to thematize. Indeed, Born has argued that such an ontology "sits uneasily" with the dynamics that open up to Gell's approach. ${ }^{17}$ Nevertheless one can readily imagine this type of thinking in a tree diagram. Beethoven 9 would be the ultimate Agent, inspiring a multitude of players through written manuscripts (turned into scores), and also inspiring Barenboim to coordinate everyone in a supreme blending action that produces a sense of "timeless emotion." This latter quality is of course a utopia, and we can recall Dyer to observe that the review's reference to tragedy hints at the reality that generates the need for that.

However, Colón's vision is clearly very partial, and bringing together the West-Eastern Divan Orchestra with Barenboim and Beethoven is only one step towards constructing the complex events that their confluence represented in 2006. A further step must consider the historical moment, indeed consider the orchestra and Beethoven 9 in the roles of Patient, because the ways in which they were presented were influenced by the war situation that was, unexpectedly, a backcloth.

The first concert took place in the famous bull ring, a venue associated primarily with fighting and bloodshed (see Fig. 4). This had been arranged long before the war began, but its aptness was discussed at press conferences, so it was thus appropriated for discussion of the orchestra's attitude to violence and the war. Additionally, organizers slipped a Declaration between the pages of the programme booklet, in which the orchestra stated unequivocally its oppositional position vis-à-vis the war (by invoking very specific unpleasant events taking place).$^{18}$ This extra layer can be incorporated into a tree diagram, in which the war (Agent) triggers concern in Barenboim and Mariam Said (Patients); they then (as Agents) ask the Orchestra's administrators to ask writers to write a Declaration; Raja Shehadah drafts a Declaration later developed by Barenboim, Mariam Said and Avi Shlaim, and it subsequently acts as an Agent on Beethoven 9-plus-West-Eastern Divan Orchestra (as Patient), affecting the significance of performances (see Fig. 5). Once the Declaration was there, the symphonic performance had a very explicit backcloth, emerging as life created in the midst of death, hope in the site of despair. This concert thus represented peace and construction, set against violence and destruction, and fulfilled Dyer's conditions for utopia very neatly,

\footnotetext{
${ }^{16}$ Carlos Colón, “La paz necesita a Beethoven,” Diario De Sevilla, 10 August 2006. All Spanish reviews are translated by Eva Moreda-Rodríguez.

${ }^{17}$ See Born, 27.

${ }^{18}$ For discussion of this Declaration, see Beckles Willson, “The Parallax Worlds.”
} 
invoking the highly problematic reality (physical violence) and apparently working it through until it disappeared (by presenting a successfully collaborative musical performance and joyful celebration).

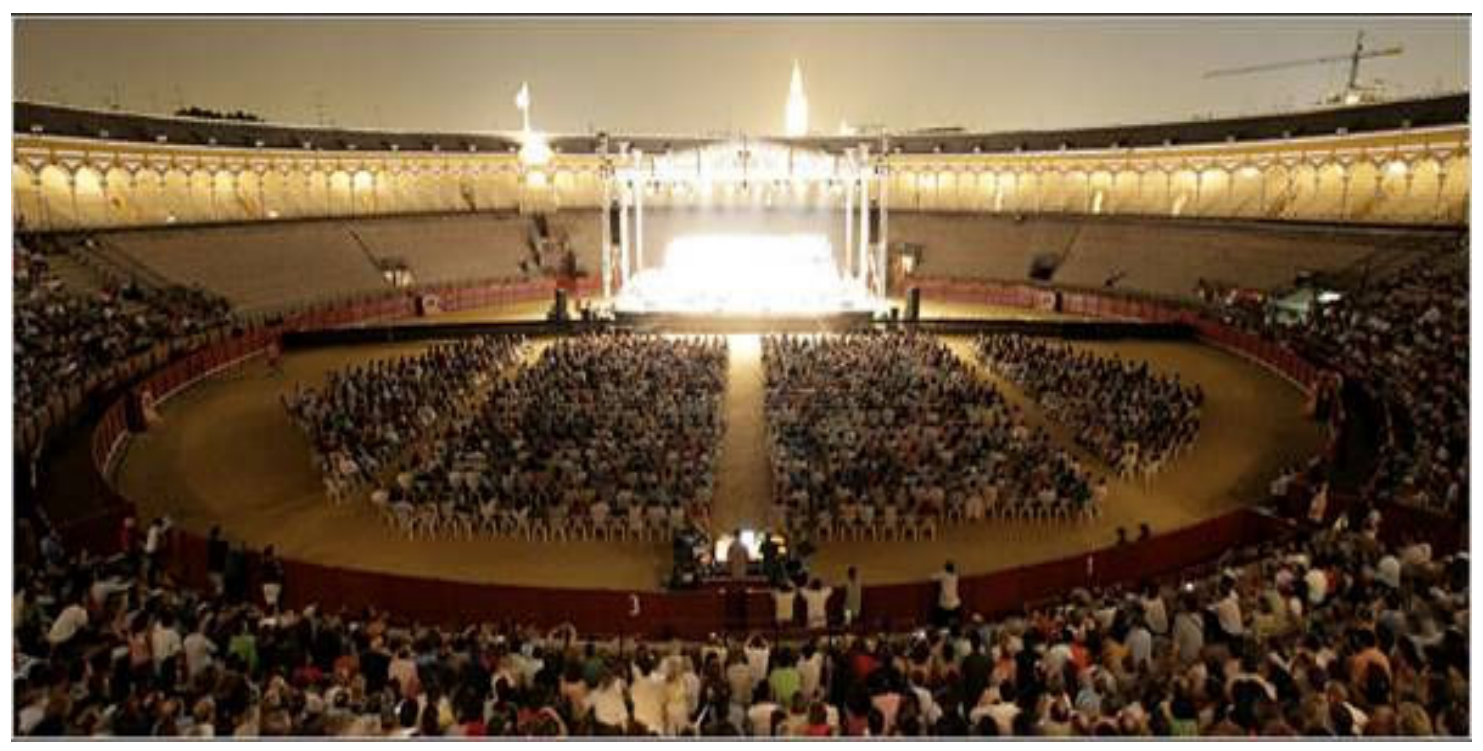

Figure 4. West-Eastern Divan Orchestra, Seville, August 2006. (CTom Fecht

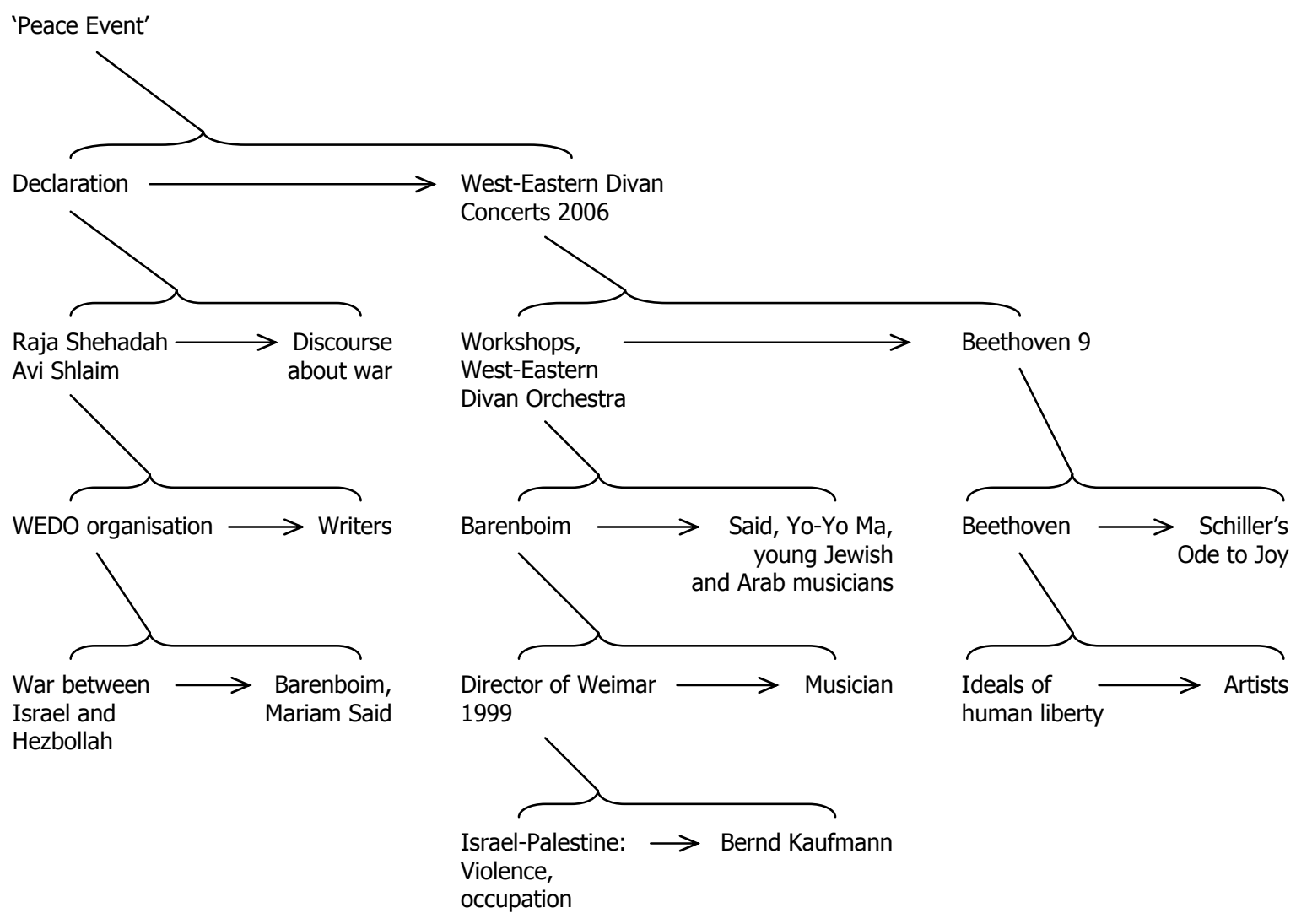


The second concert, in Madrid, was also an out-of-concert-hall experience, sponsored by the mayor of Madrid providing his annual gift to the city (Figs. 6 and 7 show the massed throngs). Although as a venue the Plaza Mayor itself offered no immediately violent context to echo the Middle East, the concert was advertised explicitly as "Music against Violence" on placards around the city, on the cover of the programme booklet, in a detailed press release, and on a vast display beside the stage (see Fig. 8). Once again, Dyer's conditions were thus met for an experience of escapism, in which the complexity of real life was invoked in order to be made to vanish. And, once again, we could incorporate this layer into a tree diagram, just as several reviewers drew it into their accounts. Several had noted that the concert in Seville was the first classical music event in the city's bull-ring, and they also mapped the "Music against Violence" statements directly onto Beethoven 9. As one put it, playing with the similarity of the two German words Freude and Friede, Schiller's poem Ode to Joy "should have been called an 'Ode to Peace' on the night that it was heard in the Plaza Mayor." ${ }^{19}$

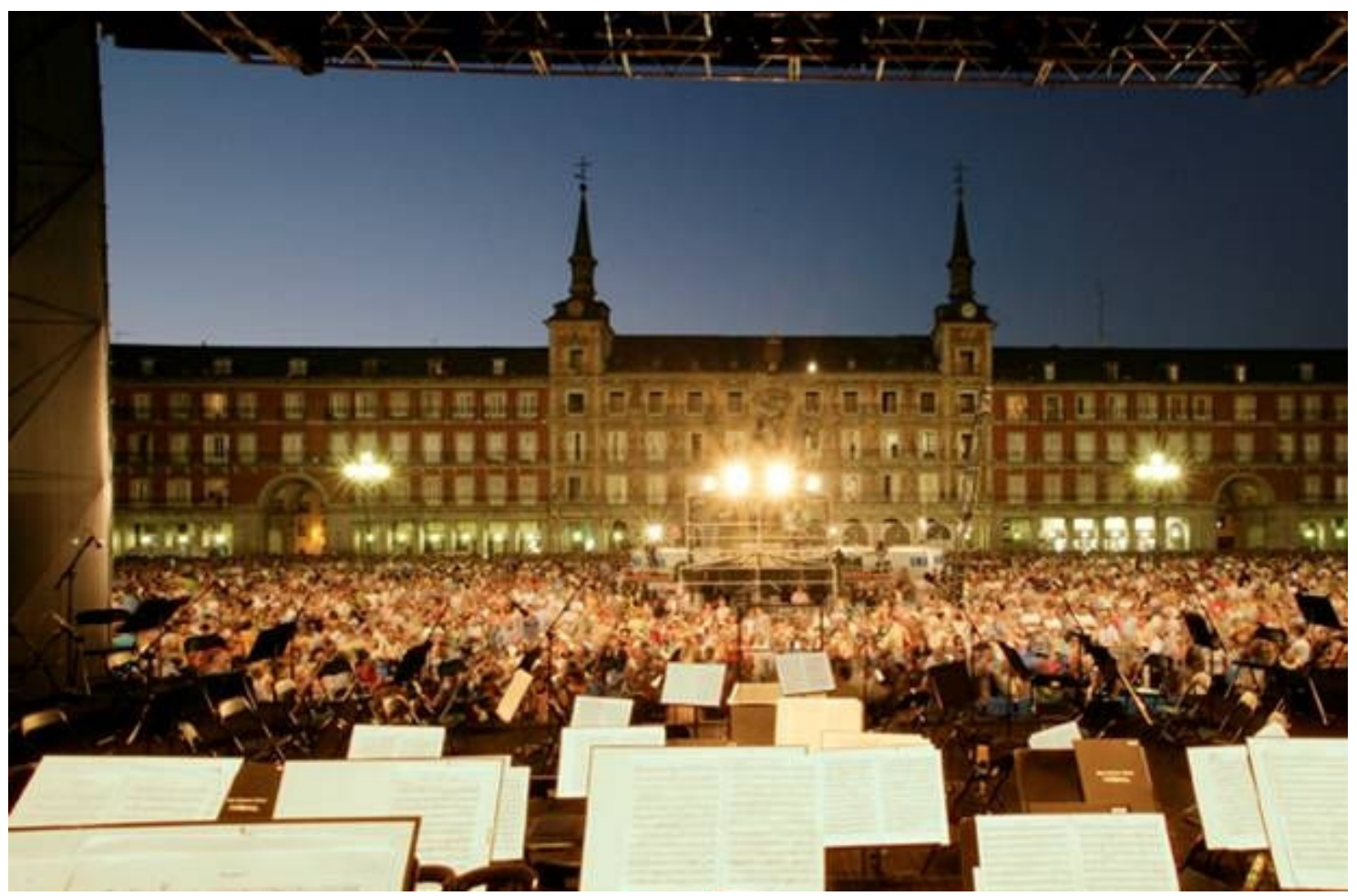

Figure 6. West-Eastern Divan Orchestral stage and audience, Madrid, August 2006. CTom Fecht

19 “Sinfonía de la Paz,” ABC Sevilla, 10 August 2006. 


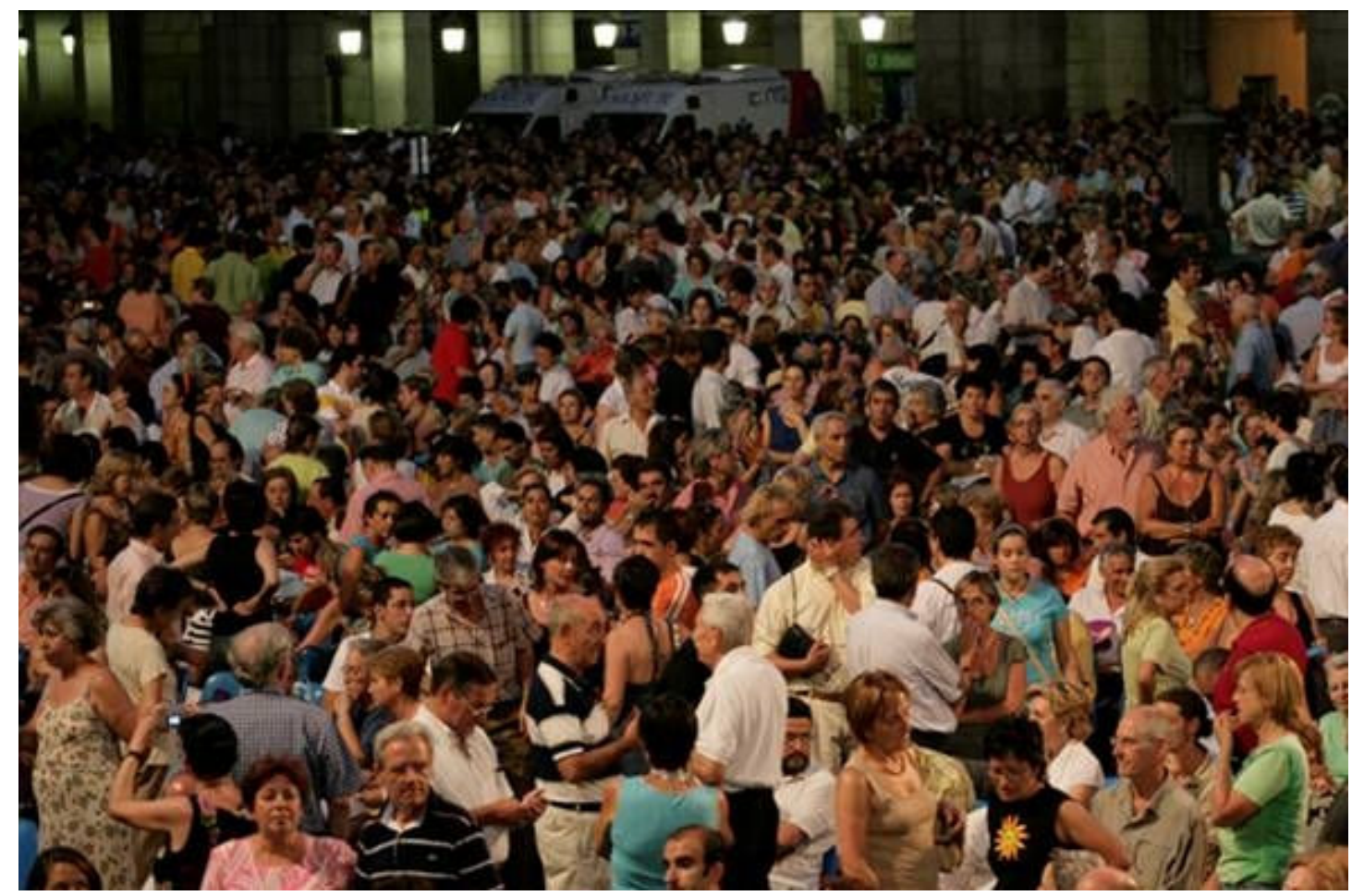

Figure 7. Crowds in Madrid for West-Eastern Divan Orchestra concert, August 2006. (C) Tom Fecht

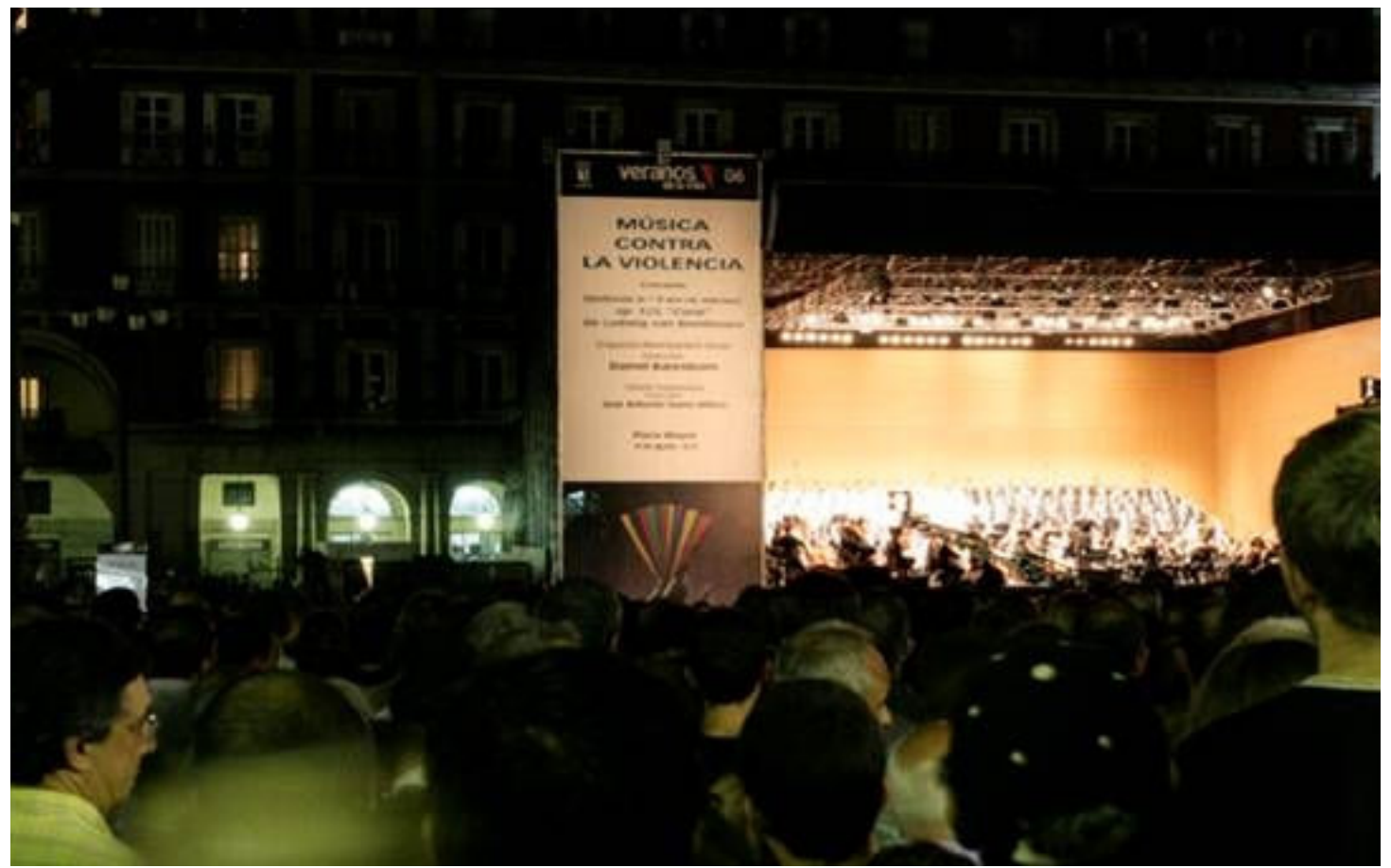

Figure 8. Stage for West-Eastern Divan Orchestra concert, Madrid, August 2006. (C) Tom Fecht 
Does the incorporation of such contexts on a tree diagram over-determine how we interpret the artistic event? On the contrary, I suggest that such a diagram can function as a theoretical constellation against which various actual responses can be read. For example, even though they were so firmly encouraged to be swept up in the utopian "peace" moment by the press conference, the setting, and the Declaration, some commentators took a more circumspect view. One article entitled "Luxury Projects" found the orchestra "culturally unobjectionable," but said that its power to confront warfare had been exaggerated. ${ }^{20}$ Another was entitled "Dreaming Peace," which made the gap between reality and orchestral utopia very clear. ${ }^{21}$

That article, moreover, takes us further in exploring the proliferating possibilities for interpretation. Rather than simply repeating the orchestra's stated opposition to the war in Israel and Lebanon, author Pablo Meléndez Haddad said that the concert tour was "a desperate cry for peace" that should be taken to "countries which still need to be convinced about the importance of peace, such as the United States, Israel or England." Plainly a reference to 20th- and 21st-century interventions in the Middle East-the most recent being the disastrous and ongoing intervention in Iraq from which Spain had withdrawn its support in 2004-this was an appropriation of the West-Eastern Divan Orchestra for Haddad's own political statement. It is comparable to what Born, with reference to Gell, has termed the "invasion of art by other orders of discourse." 22 In the next section I address some more challenging types of appropriation and invasion.

\section{Instrumentalisation, Appropriation, and Resistance}

Although many writers have realized that the orchestra's role in spreading peace will be extremely limited, and others have sensed that its projected harmony is not intact in terms of internal socio-politics, the utopian vision remains prominent in the public domain. The reason for this is not complicated: it is because it is sustained by not one, but a range of agendas (even utopias). These, I suggest, can be understood by placing the West-Eastern Divan Orchestra in various other Patient positions (even while remaining engaged with its ongoing, increasingly complex, Agent roles). I examine three of the agendas in what follows, starting with the most important, namely that of the autonomous government of Andalusia.

\section{Andalusian Utopia}

Fig. 9, showing my basic tree diagram for the Divan with some additional layers on top, introduces Andalusia's contribution. It maps out the fact that Barenboim arranged for the Andalusian government to be a prime sponsor from 2002, and that by 2004 this arrangement had been formalized into a whole government budgetary department called the Barenboim Said Foundation. This, as the diagram indicates, drew local people into creating a new music school, and establishing a permanent summer residency for the orchestra near Seville. The diagram also indicates that the impact of this on the locality drew some protest in the press, which draws us to the question not only of what the problem was, but quite why the Andalusian government chose and chooses to give so much to Barenboim's projects.

\footnotetext{
20 "Proyectos de lujo," El Mundo, 6 September 2006.

${ }^{21}$ Pablo Meléndez Haddad, "Dreaming Peace," ABC Catalun̆a, 13 August 2006.

${ }^{22}$ Born, 22. The distinction between "art" and "other orders of discourse" is nevertheless problematic, as this case makes clear. The entertainment on offer was already written through with warfare. Haddad's comments simply contributed another war.
} 


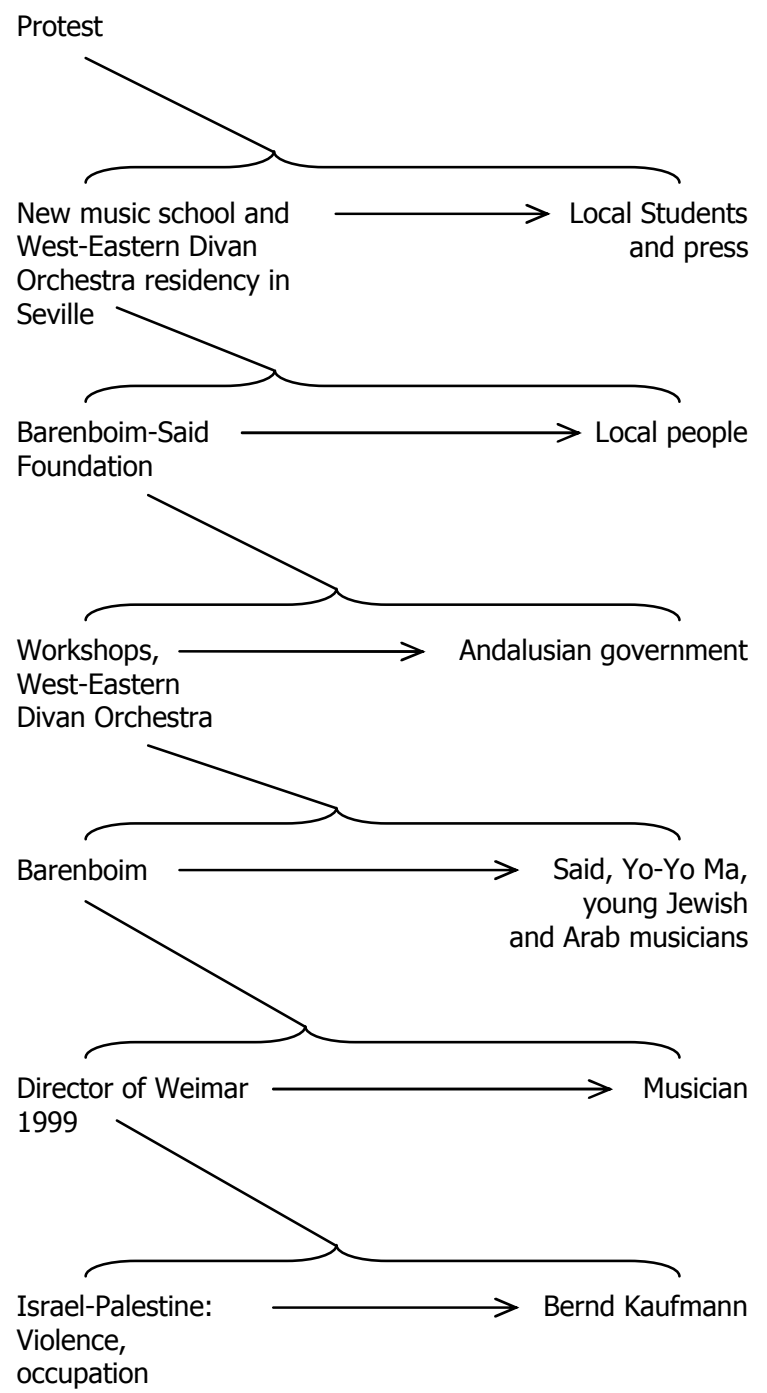

Figure 9

A significant answer can be found in Spanish politics. Since the death of Franco, Spain has gradually shifted towards a federal model of government, in which certain regions-some with the title of "historical regions"-have achieved autonomy. Andalusia reached this point in 1981, and its identity rests partly on the glorification of a moment in its history between 912 and 1009 when Christians, Jews, and Muslims coexisted relatively comfortably. Considering that moment in a positive light has been a thread of Spanish historical thought since the early 1930s, but could only come to political fruition after Franco.

One of many cultural-political products of the development was a government organization called the Three Cultures Foundation established in 1999, which was designed to promote dialogue between Morocco, Spain, and other Mediterranean regions. The Barenboim-Said Foundation is its descendant, and the model of three-way coexistence is embodied in the diverse but apparently harmonious personnel of the West-Eastern Divan Orchestra. The orchestra can thus function as an apparent enacting of Andalusia's greatest moment, and somewhat covertly enters the orbit of Andalucismo, or Andalusian nationalism, 
fulfilling what historian Khalid Duran has called "Andalusia's nostalgia for progress." 23 Thanks to Barenboim's enormous prominence in Europe and the United States, this projection of Andalusia is disseminated extremely widely. In 2006 it was peculiarly ironic that Beethoven 9, a work composed on the cusp of the European nationalist movements, became thereby a vessel through which Europe and the U.S.A. could idealize a moment in Spain's history when it was ruled by a Muslim Caliphate. The irony was particularly keen given contemporary European and American anxiety about Islam.

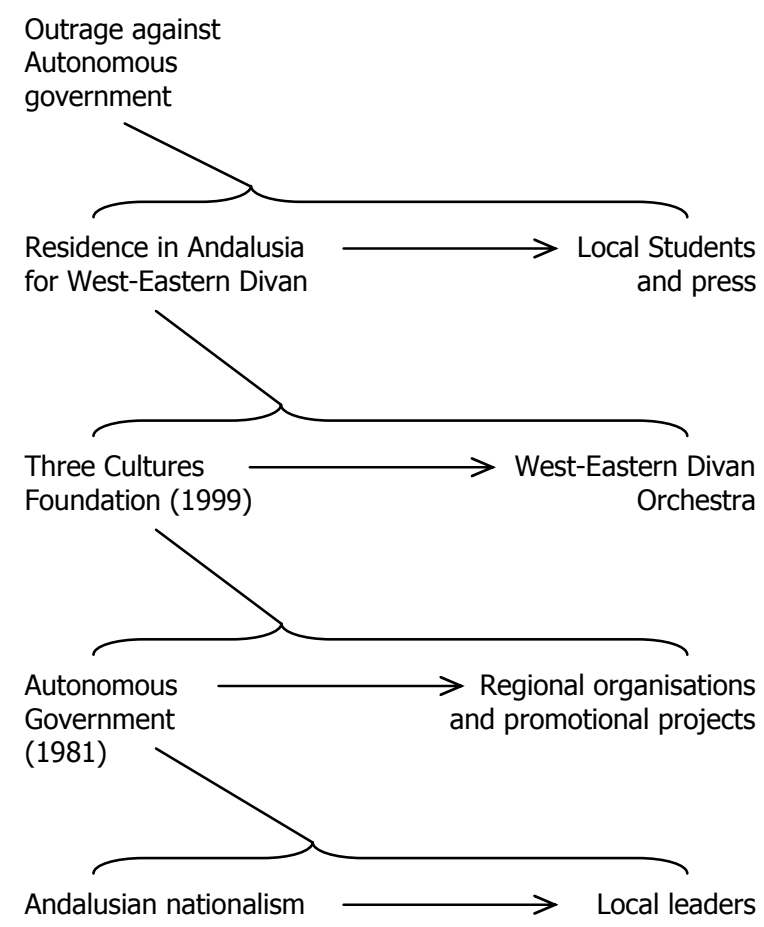

Figure 10

The predictably controversial Spanish reaction to this (ironic) utopia can be traced in Fig. 10, which builds towards public expressions of anger that the government spends money on glossy Divan performances at the expense of local music schools and orchestras. When Barenboim was conducting Parsifal in Seville in 2005, about 25 students from local music schools demonstrated outside the theatre in protest against the government's funding of the West-Eastern Divan Orchestra. ${ }^{24}$ In 2006, three of the newspapers covering the Divan's concerts complained similarly. The points made were that Barenboim was a "scrounger," "spoiled by the government," that he receives nearly double the budget of the Malaga

\footnotetext{
${ }^{23}$ Khalid Duran, “Andalusia's Nostalgia for Progress and Harmonious Heresy,” Middle East Report 178 (September-October 1992): 20-23. For more positive engagements with Andalusian multiculturalism, see Sanaa Osseiran, ed., Cultural Symbiosis in Al-Andalus: A Metaphor for Peace (Beirut: UNESCO Regional Office for Education in the Arab States, 2004).

${ }^{24}$ Author's interview with HG (Syria), who participated in the orchestra in 2001 and 2005. New York, 9 February 2005.
} 
Symphony Orchestra, and deprives impoverished local music schools of cash. ${ }^{25}$ This financial friction can be sensed from players in the orchestra too, because it is by no means easy to gain information about Andalusian resistance to the orchestra from them: their place inside the orchestral club forecloses admission of its impact on their (less fortunate) compatriots outside. The utopian projection of (Golden Age) ethnic and religious inclusiveness may seem hollow once placed within current political realities, anxiety about economics, and competitive professional exclusivity.

\section{Palestinian Utopia}

While the orchestra embodies and thus projects co-existence between Arabs, Jews, and Europeans, both Said's writings, and Barenboim's public political statements, have frequently honed in on an explicit criticism of the Israeli government's foreign policy. Barenboim has often stated that Israel should move out of the Palestinian territories it has occupied illegally since 1967, and support the formation of a Palestinian state. In line with this position, the concert in Madrid triggered a demonstration which is illustrated in Fig. 11. About ten Palestinians joined the thronging audience carrying a banner bearing the text "End the Occupation for Peace in Lebanon and Palestine," which they held up throughout the concert at the back of the square facing the orchestra directly. They distributed leaflets about the history of Palestine and the warring situation there, and some waved Palestinian flags.

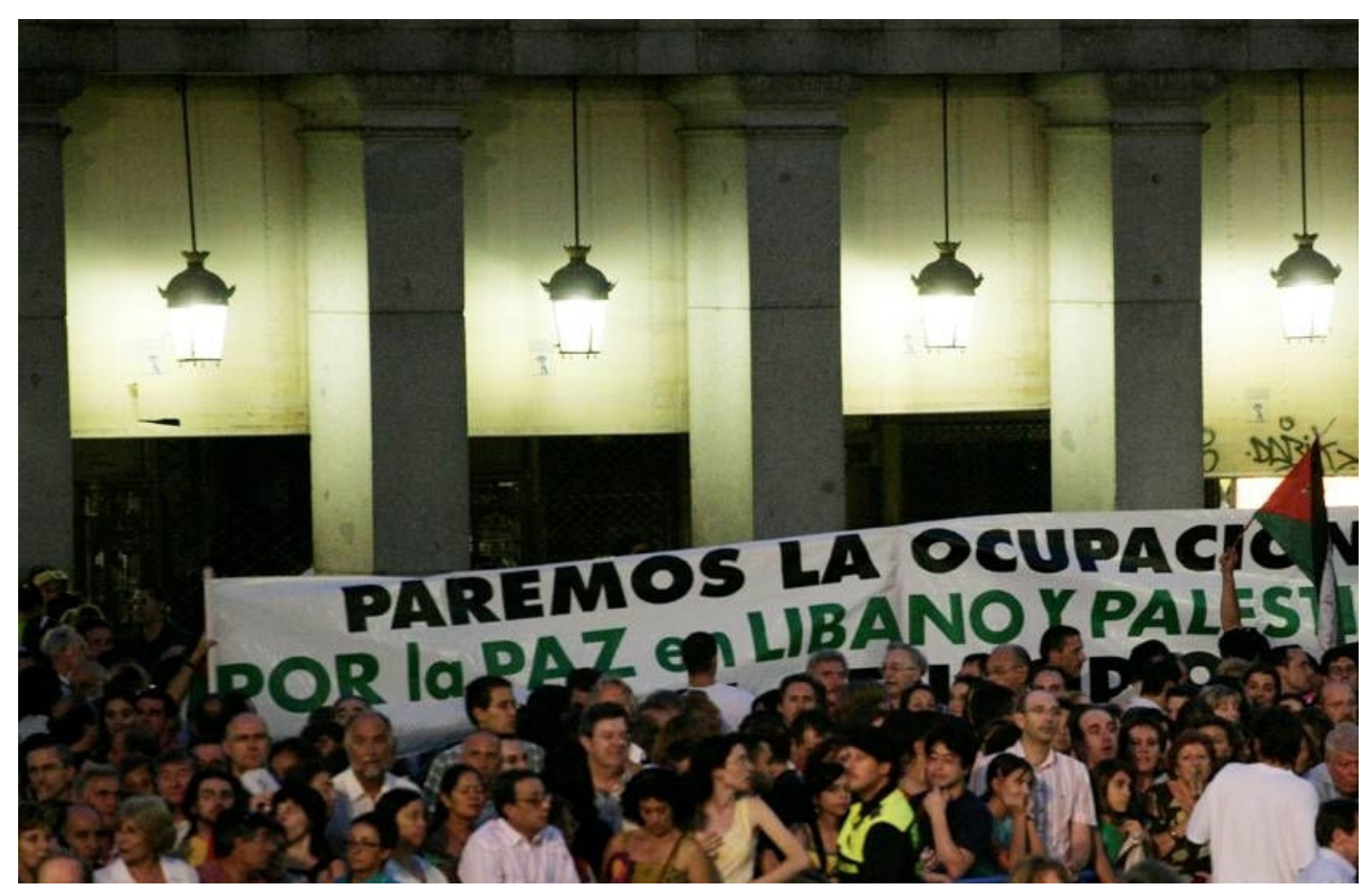

Figure 11. Demonstration at West-Eastern Divan Orchestra concert, Madrid, August 2006. CTom Fecht

\footnotetext{
25 "La ciudad de los mangazos" [The city of mangazos], ABC Sevilla, 1 September 2006; "El músico mimado por la Junta" [The musician spoiled by the Junta], Diario de Ferez, 3 September 2006; "Proyectos de lujo" [Luxury Projects], El Mundo, 6 September 2006.
} 
In order to draw this into the analysis presented thus far, I introduce a further tree diagram, shown in Fig. 12. It begins with the formation of the state of Israel in 1948, which was simultaneously an act of enormous violence within the region known until then as Palestine (Patient). One consequence was a refugee problem in the Arab communities. The refugees acted among themselves (Agents and Patients) to organize solidarity campaign groups in many countries. These groups (as Agents) undertook a variety of activities, including demonstrations. And one of those demonstrations took place on the Plaza Mayor, Madrid, on 10 August 2006, actively influencing the West-Eastern Divan Orchestra concert. Thus we can bring all the trees together (Fig. 13).

On a very superficial level, this was a peaceful and (to many) a welcome demonstration, an act of appropriation only in its opportunism. In line with the orchestra's declaration of 2006, it opposed the war, and as one of the Palestinian demonstrators said to me, "we are so happy to be here, it is great what Barenboim is doing." However, whatever Barenboim says about Israel's occupation of the Palestinian territories to the press, his orchestra does not perform withdrawal and separation, but co-existence. The demonstrators, on the other hand, were not a mixed group, but came from Palestine only, and their message was a protest against Israeli action. To this extent they were interlopers in a European dream, representing the dreams of Arab people in Palestine, and not necessarily exactly those of (say) Bernd Kaufmann or indeed the Andalusian government from Europe.

Essentially their presence challenged the obfuscatory rhetoric according to which the problem in the Middle East is that people are unaware of "the other," because it brought the occupation to the fore, and therefore the radically unbalanced political and economic relations between Israelis and Palestinians, and the violence that is ongoing. Whereas in Europe coexistence is a popular utopia, for those in the region it is qualified by so many prerequisites as to be largely unavailable. As writer Ghada Karmi put it, "[r]econciliation and togetherness are consequences of a settlement, not antecedents to it." ${ }^{26}$ Composer and oud player Khaled Jubran has argued similarly against using music to project an artificial political union. In his words: "music has never brought hearts closer. Certainly not the hearts of two nations that despise each other."

Unsurprisingly, then, some Israeli players were dismayed by the demonstration. One said that it was "horrible but I ignored it," while another said "it was painful to have to see it facing us directly during the concert," and argued that the music should be all about "smiling and happiness." ${ }^{8}$ She felt that this happiness was what the audience wanted, and was what the Divan could best offer. For these players the reminder of the real experiences was combined with an accusation, suggesting explicitly that the problems in the region were caused by the Israeli nation. Thus their own dreams of a solution were obstructed. Even while they attempted to transcend the political situation by playing Beethoven, moreover, the banner stayed on high, and the flags were waved. As Dyer has pointed out, "the utopian sensibility has to take off from ... real experiences," but "to draw attention to the gap between what is and what could be is, ideologically speaking, playing with fire." 29

\footnotetext{
${ }^{26}$ Ghada Karmi, "Can Jews and Arabs Use the Arts and Work Together for Peace?," first published in Arabic in Al-Hayat in August 2003, reproduced in English by the Levantine Cultural Centre, http://www.levantinecenter.org/pages/ghada_karmi_page.html, accessed 2 December 2005.

${ }^{27}$ See "Prominent Arab Musician Doubts the Value of Music as Tool to Promote Peace," reproducing extracts from Ha'aretz, 2 April 2002, www.andante.com, accessed 15 April 2006.

${ }^{28}$ Interview with XZ (Israel), Weimar, August 2006; Interview with YT (Israel), Istanbul, August 2006.

${ }^{29}$ Dyer, 34.
} 


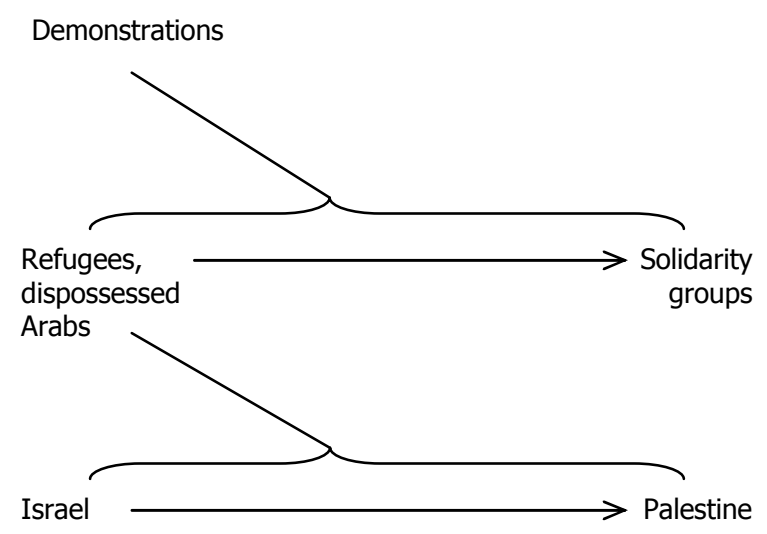

Figure 12

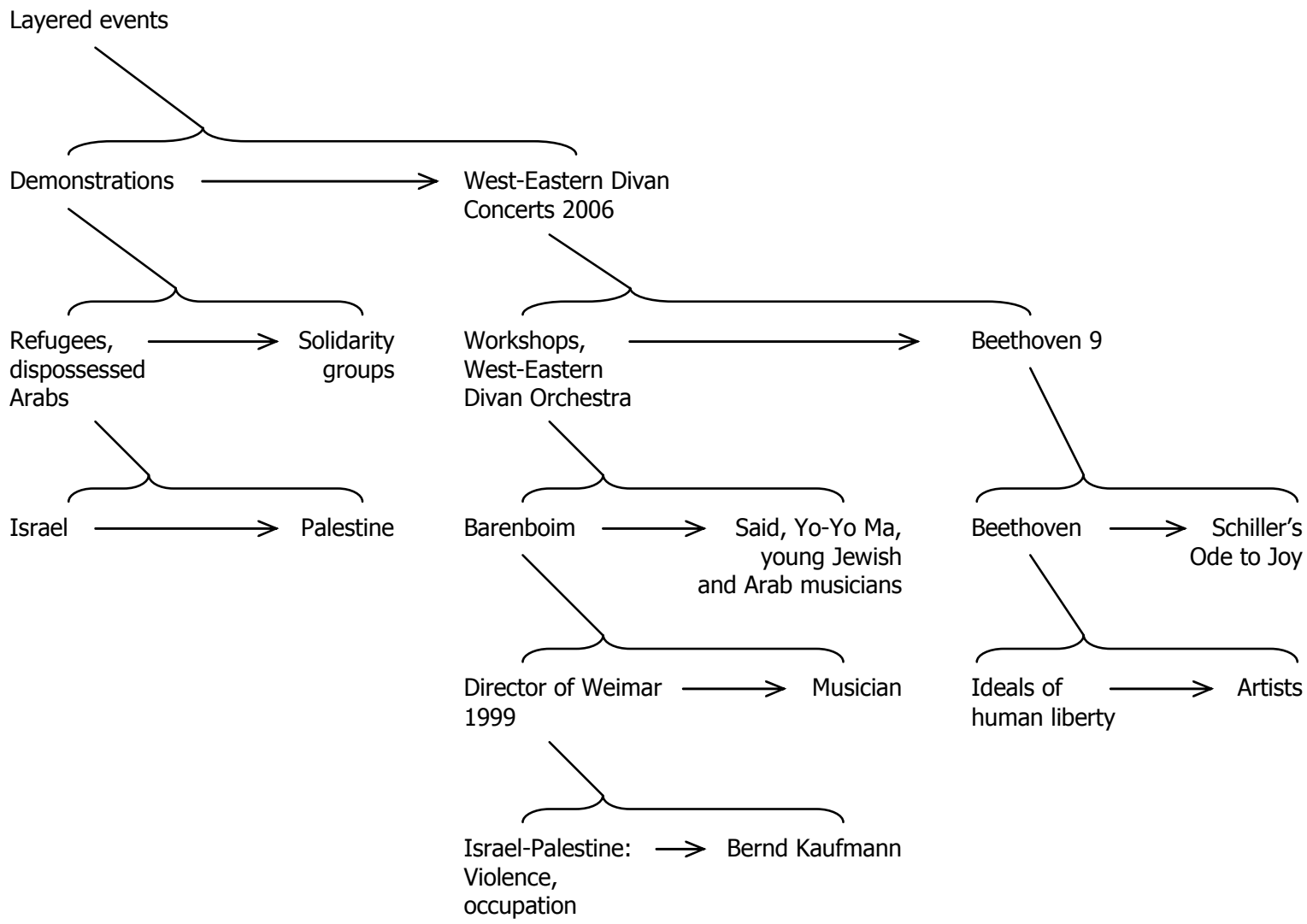

Figure 13 
In fact the position of these Israelis can be placed in a broader historical context, one which allows us to see their conflicted orchestral experiences within a network of relationships between human liberty and nationhood. There is, for example, a strong link between the human liberty that inspired Schiller, and the desire for autonomy among Jews in Palestine: it is the nation state. Indeed the Zionist movement, which contributed to the vast influx of Jews to Palestine in the first half of the twentieth century, is inseparable from the chain of national formations that unfolded following the time of Schiller. In Palestine itself, a national discourse (sometimes in competition with an Arab national discourse) is already to be traced in Arabic publications from the first decades of the twentieth century, while the collapse of the Ottoman Empire in 1918 gave it more space, the very conspicuous arrival of Zionists thereafter made it more urgent. ${ }^{30}$ Finally, the establishment of a national Jewish state in 1948 — as the dispossessed Arabs of Fig. 12 remind us-carried all the violence of the French Revolution, and echoes with the dismay lying behind Schiller's textual alteration, and Beethoven's adaptation. By this time the over-simplified nature of my much earlier Fig. 2 may be forgiven, given the complexity with which Beethoven 9 can now be considered quite apart from its genealogy. Even if Gell's diagrams are open to criticism for their apparent fixity, the combination of the elements on the right side of Fig. 13 (Schiller), with those on the left (dispossessed Arabs) should be unfamiliar enough to trigger further, and renewed, reflection on the contingency of all the connections and interpretations that the diagrams portray.

Given Barenboim's position regarding Israel's occupation, one can safely say that the West-Eastern Divan Orchestra concert was ostensibly trying to make a counter-performance against the occupation of Palestinian territories that Israel has practised since 1967, as a first step towards a Palestinian nation and (thereafter) coexistence. But for (at least) two Israelis, it was hard to have Palestinian and Lebanese needs projected without their own needs being placed alongside; and perhaps it was also hard to be reminded that Palestinian liberty might come at a price to them. The exclusionary nationalist utopias continue to compete very strongly within the orchestral utopia of coexistence.

\section{Occidental Utopia}

Clearly, then, for some players in the orchestra, signs of the political conflict-whether in placards, press interviews or even Palestinian demonstrators-are less than welcome. Such signs tend towards a repetitive construction of a dream with which many do not feel comfortable. That is not to say that some of their problems (Dyer's "real experiences") cannot be "worked through" in the context of playing a symphony, but that the latter needs to displace the former, thoroughly erasing it. At the same time the matter is more complex than it seems, because many of the "real experiences" from which they wish to escape are not ones that the orchestra discusses in public.

To present this more transparently, Fig. 14 offers an alternative tree diagram of the West-Eastern Divan Orchestra, one based on the desires of the majority of players, and their consequent activity. At base, and turning the clock back a little, we can see that musicians come into being through the intervention of music education. On the next level, we see that some then seek out or compete for opportunities to play in ensembles, with the result that orchestras are formed-in this case, the WestEastern Divan Orchestra. Once in an orchestra, the hope of many musicians is to continue the orchestral

\footnotetext{
${ }^{30}$ Rashid Khalidi, Palestinian Identity: The Construction of Modern National Consciousness (New York: Columbia University Press, 1997), 145-176.
} 
life, and they compete for further opportunities. In this particular case they use the Barenboim-Said Foundation, which administers scholarships for which orchestral members can apply at the end of the annual concert tour. Having become students in Europe and the U.S.A., many of these players then wish to take advantage of career opportunities in these places. For most of them the heightened glamour of working with Barenboim cannot be sustained in an ongoing professional situation (that would be a true utopia); but his orchestra does enable some of them to escape from the relatively limited professional and economic possibilities in Israel and the Arab countries, and settle outside the region.

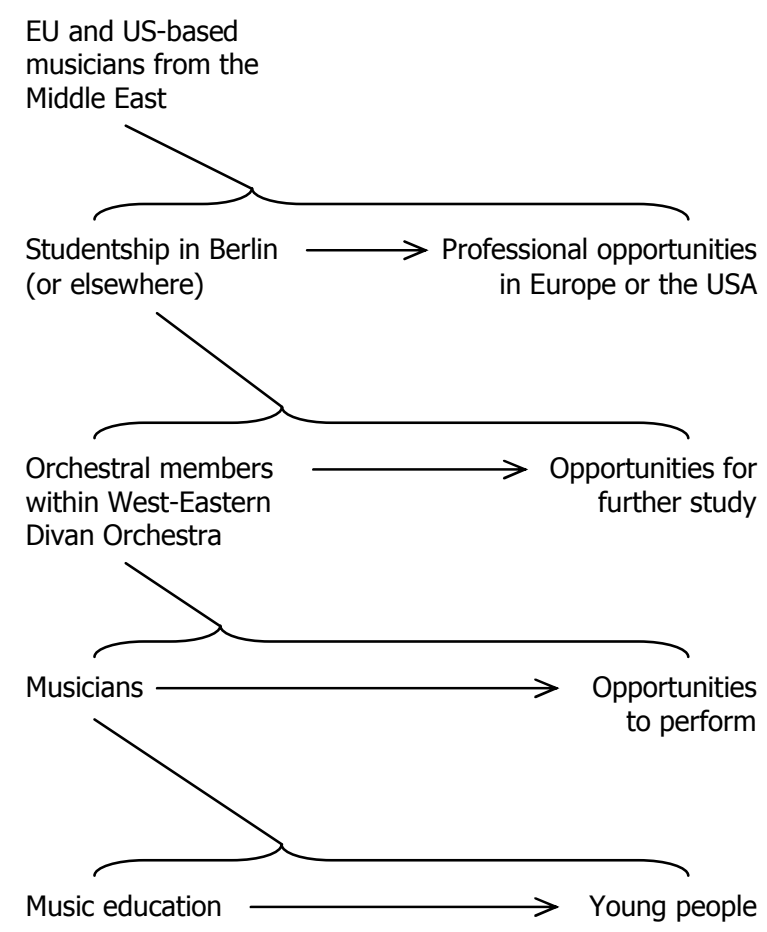

Figure 14

This admittedly rather telescopic scheme serves the purpose of exposing and counteracting the Orientalist vision that many from outside the Middle East employ when viewing the West-Eastern Divan Orchestra. The vision romanticizes the players variously with notions of primitiveness, violence, and passion, and cloaks them in a vessel of Eurocentric elevation in a movement of rejoicing that is, at base, self-congratulation. Beethoven, as we have already seen, saves them from themselves. But although players also desire the vessel of Eurocentric elevation, they do so for different reasons. On the one hand, they desire to save themselves from Orientalist stereotypes, but on the other, from economic disadvantage.

As one Israeli player said in Madrid, when asked by the local press as he left the Plaza Major what it was like playing with Jews and Arabs together, the question was "irrelevant," because the orchestra had 
"one voice." 31 The player claimed in the same conversation to be unaware that the Syrians and Lebanese were absent because of the war. Speaking thus, he erased the war, indeed exorcized memories of the obstacle to the orchestra's complete attendance that year, and even the primary raison d'être of the orchestra as projected to the public, namely the collaboration between such political estranged people as Lebanese, Syrians, and himself. Instead, he invoked one of Barenboim's stock phrases about the singularity of the orchestra's voice, because his utopia—at that moment—was about being a musician who could partake in musical activity irrespective of his ethnicity or religion. Thus the symphony orchestra and Beethoven 9 wrapped up an exoticized oriental background, made it (all but) disappear, and many were made happier by that.

\section{The Final Utopia}

At the beginning of this article I observed a music-discourse split within Barenboim's construction of his "utopian republic." At times he wished to emphasize that musical interaction in itself generated an ideal sociality, while at other times he was as interested to point to the orchestra's more discursive educational component, one involving the breakdown of national or ethnic stereotyping. The split can be traced similarly in the thinking of Edward W. Said, so I close by examining that, with a view to mapping the extent to which "utopia" captures the place that the orchestra occupied for Said at the end of his life.

One of his last books, Humanism and Democratic Criticism (2004), offers an immediate indication of how he saw his role in that debate, because within that book he put forward a manifold programme for the humanist intellectual which included "discern[ing] the possibilities for active intervention," acknowledging or directly participating in film, photography and music that challenged prevailing beliefs or political situations, and providing alternatives to "fields of battle" by constructing "fields of coexistence." 32 Indeed even in the rather limited traces we have of his view of the West-Eastern Divan Orchestra specifically, his interest in exploring this humanistic potential is very clear. His speech on being awarded the Prince of Asturias Award for Concord in Spain in 2002 included the following statement:

Strange as it may seem, it is culture generally and music in particular that provide an alternative model for the conflict of identities. My friend Daniel Barenboim and I have chosen this course for humanistic, rather than political reasons on the assumption that ignorance is not a strategy for sustainable survival. ${ }^{33}$

Correcting ignorance was a primary feature of the first orchestral workshop, because it brought together people from backgrounds in which they were conditioned to be hostile to one another, it challenged them and educated them with critical discussion, and it opened to them "the practice of identities other than those given by the flag or the national war of the moment." 34 Said believed that the young musicians were "changed" by the contact that they had with one another, and that this was something to strive for. ${ }^{35}$

Let us look more closely, then, at the changes he identified and celebrated. As already hinted above, one was precisely in line with his humanistic concerns, namely the way that the music-making had

\footnotetext{
${ }^{31} \mathrm{~GB}, 10$ August, 2006. I overheard this conversation.

${ }^{32}$ Edward W. Said, Humanism and Democratic Criticism (Basingstoke: Palgrave MacMillan, 2004), 140 and 141.

${ }^{33}$ See Smaczny, The Ramallah Concert, Track 5.

${ }^{34}$ Said, Humanism and Democratic Criticism, 80.

${ }^{35}$ See Smaczny, Daniel Barenboim, Track 11, and Barenboim and Said, 6-10.
} 
triggered a reconfiguration of perceptions about people's capacities as national subjects. For instance, there were conflicts at the workshop in 1999 where someone made a claim on a certain repertoire, linking it exclusively to national identity and thus policing the people who could access it. Such conflicts were the opportunity for developing an argument, and then a reasoned discussion, and a consequence was the renunciation of exclusive, essentialist claims. ${ }^{36}$ As Peter Tregear has argued, cross-cultural musical practice can enhance such fluidity. In his words, the "inhabiting of an artistic style by a culture that otherwise might be thought to be estranged from it [is] an act of considerable critical potential." ${ }^{37}$

On the other hand, however, Said also described an entirely different process of change in which the national backgrounds of players became irrelevant when Barenboim raised his baton in front of them. ${ }^{38}$ At such moments, plainly it was not discourse that altered their identity, but an (enthralled?) desire to participate in the musical experience led by Barenboim. To be sure, one might argue that this was leading to a desirable fluidity among them, but Said's perception of this change was clearly a consequence of his personal experiences of music-making, which, as Ben Etherington has argued, "led him to assert the intrinsic value of Western elite music without really exploring how that tradition escapes mediation." ${ }^{39}$ Said himself admitted that his view was "romantic," and if we draw directly on his thoughts from 1991 we can surmise that, for him, when players came under the spell of Barenboim, they had entered a different realm entirely from their worldly political existence. As he put it, "music to a consummate musician possesses a separate status and place ... that is occasionally revealed but more often withheld."

That particular comment, however, opens up the music-discourse split very wide, because the musical transformation implied is as closely aligned with religion as with romanticism, and indeed a religion involving a renunciation of responsibility (hoping that revelation will not be withheld). William D. Hart has convincingly argued that Said frequently wrote of music in precisely the terms of private revelation associated with religious experience, and that this is in problematic opposition to his abhorrence of religious practice, and his insistence that humanistic processes must by definition be secular and antireligious. ${ }^{41}$ While Said acknowledged that music was "part of the cultural life of modern society," he simultaneously sought to preserve its musical activities in a quasi-sacred sphere, not only "a uniquely endowed site" ${ }^{42}$ but also a "separate status and place."

Notoriously, Said's writing constructs, maintains, and negotiates the split with dialectics. Striving to separate art from the sordid nature of the world in general, he said that "it exists intensely in a state of unreconciled opposition to the depredations of daily life, the uncontrollable mystery on the bestial floor." It was the task of the humanist, he said, to "accept responsibility for maintaining rather than resolving the tension between the aesthetic and the national, using the former to challenge, re-examine and resist the latter." 44 This proposition for academic activity has long been subject to serious critique by other scholars, but as an ideal comportment within an orchestra it seems yet more problematic. According to Said, the

\footnotetext{
${ }^{36}$ Barenboim and Said, 8-10.

${ }^{37}$ Peter Tregear, "Edward Said and Theodor Adorno: The Musician as Public Intellectual," in Edward Said: Legacy of a Public Intellectual, ed. Ned Curthoys and Debjani Ganguly (Melbourne: Melbourne University Press, 2007), 213.

${ }^{38}$ Smaczny, Daniel Barenboim, Track 11, and Barenboim and Said, 9-10. See also Beckles Willson, "The Parallax Worlds" for more extensive discussion of players' interaction with Barenboim, along precisely these lines.

${ }^{39}$ Ben Etherington, "Said, Grainger and the Ethics of Polyphony," in Curthoys and Ganguly, 235.

${ }^{40}$ Edward W. Said, Musical Elaborations (New York: Columbia University Press, 1991), xv-xvi.

${ }^{41}$ William D. Hart, Edward Said and the Religious Effects of Culture (Cambridge: Cambridge University Press, 2000), 37-38.

${ }^{42}$ Said, Musical Elaborations, xvi.

${ }^{43}$ Said, Humanism and Democratic Criticism, 63.

${ }^{44}$ Ibid., 78.
} 
dialectical humanistic task was to be carried out "in those slow but rational modes of reception and understanding which is the humanist's way;" but it is not clear that this painstaking process can be realistically aligned with the activities of many violinists playing Tchaikovsky.

In fact, and even though we have seen that players in the West-Eastern Divan Orchestra do not renounce their backgrounds when they start to play, they are indeed encouraged to access Said's "separate status and place," and the chosen repertoire will often generate a totalising, synthetic, teleological and monumental sphere. Ben Etherington has argued that it is a far cry from the "contrapuntal," "dissonant," or "resistant" qualities that Said sought when he discussed humanistic criticism. ${ }^{45}$ Elsewhere I have interrogated the way this repertoire interacts with political tension, and on the basis of ethnographic research concur that the access tends to function as an affirmatively synthetic (and intoxicating) experience. ${ }^{46}$ Can it, then, be used in Said's dialectical fashion to "challenge, re-examine and resist" nationalism? The problem is that each realm (playing the repertoire and being nationalistic) is unlike what Said celebrates in humanism, namely "the critical sense of inquiry": each comes much more in line with what he calls, following Julien Benda, "the mobilization of collective passions." 47 And even if the musical activity resists "nationalism," it tends towards another type of essentialism, namely an unmeasured sense of superiority in its own aesthetic autonomy.

Said attempted to move away from the music-discourse split when he suggested that the players coming together "in concert" could offer "an alternative model for the conflict of identities." ${ }^{" 48}$ His suggestion did not draw exclusively on his position vis-à-vis the role of the humanist, but also on his thesis about western classical music's role in the development of civil society. Rhetorically, this might seem more promising, but his thesis never demonstrated a helpful or practical connection. Rather, it made claims according to which western classical music elaborated (and thus sustained) processes in ways that could be understood, through Gramsci, as characteristic of civil society. ${ }^{49}$ What was missing from his account was an analysis of the society ("civil" or not "civil") that the western classical musical practice itself "elaborated" beyond musical textures during the music-making moments, or indeed recognition that other communal activities such as sports might offer comparable or preferable paradigms for co-existence. In short, he omitted to make "a radical examination of the ideology of the [musical performance] field itself." Perhaps the West-Eastern Divan Orchestra would have been a medium through which he could have done that had he lived longer, but it is difficult to imagine that he would have had the wherewithal to do so, given his preservationist attitude towards western classical music, and his hostility towards musics that have plainly contributed to civil society in more obvious ways. ${ }^{51}$

\footnotetext{
${ }^{45}$ Ben Etherington, "Instrumentalising Musical Ethics: Said and the West-Eastern Divan Orchestra," Australasian Music Research 9 (2007): 121-29. Nevertheless, Barenboim expanded the Divan's repertoire in 2007 to include Schoenberg's Variations for Orchestra, op. 31.

${ }^{46}$ Beckles Willson, "The Parallax Worlds."

${ }^{47}$ Said, Humanism and Democratic Criticism, 37.

${ }^{48}$ Speech on receipt of the Prince of Asturias Award for Concord, Spain, 2002. See Smaczny, The Ramallah Concert, Track 5.

${ }^{49}$ Said, Musical Elaborations, 15: "The fact is that music remains situated within the social context as a special variety of aesthetic and cultural experience that contributes to what, following Gramsci, we might call the elaboration or production of civil society. In Gramsci's usage elaboration equals maintenance, that is, the work done by members of a society that keeps things going; certainly musical performance fits the description, as do cultural activities like lectures, conferences, graduation ceremonies, awards banquets, etc. The problematics of great music performance, social as well as technical, therefore provide us with a post-Adornian occasion for analysis and for reflecting on the role of classical music in contemporary Western society."

${ }^{50}$ Said, Humanism and Democratic Criticism, 38. This was what he said scholars of literature had failed to do for their field.

${ }^{51}$ Hart, 33, provides examples of Billie Holiday's "Strange Fruit," Bob Marley's “Them Belly Full (But We Hungry)," and the anthem of the Civil Rights Movement, among others.
} 
It seems profoundly ironic that Said was one of the legitimations of the West-Eastern Divan Orchestra, and that his authority in the Arab world won trust and provided encouragement to potential participants. Evidently he sought to draw people into his own "humanistic" and musical space, one that it is difficult not to see as another Euro-American vision-if a relatively powerless one-among the endlessly proliferating visions for Palestine. As he put it, "what is so heartening is how many young people have responded, and how even in this most difficult time young Palestinians have chosen to study music, learn an instrument, practise their art. Who knows how far we will go, and whose minds we might change." ${ }^{, 2}$ But in the context of people on the ground in Israel and Palestine itself, is the change feasible? Is it broadly useful? It is tempting to invoke Ilan Pappé's remarks about Christian missionaries in the same space, for whom "the locals were spiritual commodities, with which they hoped to enlarge the community of Christian believers." ${ }^{53}$ It might be seductive to believe that joining, and being "changed" by, a western classical music orchestra is a useful step for many Palestinians. But we would do well to recognize the problematic utopia that such a belief embodies.

\begin{abstract}
The West-Eastern Divan Orchestra, described by its founder conductor Daniel Barenboim as a "utopian republic," is a much publicized example of the contemporary trend for engaging western classical music with social concerns. In this article I situate it in the context of Richard Dyer's reflections on musical utopia, and take the concerts that it presented in the summer of 2006 as case studies. I also explore the potential of Alfred Gell's theory of art to problematize the singularity of the orchestra's utopian projection (harmonious collaboration between Arabs and Jews) and expose a range of competing utopias that sustain it. As an epilogue, I contribute to the debate about how we can contextualize the orchestra within the thinking of its former intellectual figurehead, the late Edward W. Said.
\end{abstract}

\footnotetext{
${ }^{52}$ Speech on receipt of the Prince of Asturias Award for Concord, Spain, 2002. See Smaczny, The Ramallah Concert, Track 5.

${ }^{53}$ Ilan Pappé, A History of Modern Palestine: One Land, Two Peoples (Port Melbourne: Cambridge University Press, 2004$), 42$.
} 